\title{
Nutritional Composition, Functional and Organoleptic Properties of Breakfast Cereals Formulated from Acha, Wheat, Cashew Kernel and Prawn
}

\author{
N. J. T. Emelike, S. C. Achinewhu, and C. O. Ebere
}

\begin{abstract}
Acha grains and cashew kernels were processed into flour while prawn was processed into powder. Acha flour was used to substitute wheat flour while a constant percentage of cashew kernel flour and prawn was used as an enrichment in the formulation of breakfast cereals at the ratios of 70:0:20:10, 60:10:20:10, 50:20:20:10, 40:30:20:10, 30:40:20:10, 20:50:20:10, 10:60:20:10 and 0:70:20:10 of acha/wheat/cashew kernel/prawn and labeled $A-H$ samples, respectively. The nutritional, functional and organoleptic properties of the formulated breakfast cereal was studied. The result revealed that the proximate compositions of the breakfast cereals ranged between 3.94-9.46\% for moisture content, ash 2.09$2.98 \%$, fat 8.30-15.20\%, protein 9.17-14.65\%, crude fibre 1.28$1.60 \%$, and carbohydrate $60.97-76.66 \%$ with significant different (SD) between some samples and no SD in some other samples. Functional properties' result showed that the bulk density of the breakfast cereals ranged between $0.49-0.55 \mathrm{~g} / \mathrm{g}$, water absorption capacity 1.74-2.20 g/ml, oil absorption 0.18 $1.09 \mathrm{~g} / \mathrm{ml}$ and the least gelation capacity of $2 \%$ in all the samples. Based on the 9-point hedonic scale used in the assessment of the organoleptic properties of the breakfast cereals, all the samples were acceptable by the panelists but 40:30 of acha/wheat compared very well with the sample substituted with 0:70 of acha/wheat. This is an indication that acha grains can be a useful raw material in the substitution of wheat while cashew kernel and prawn can be used to enrich the product formulated from the flours of these raw materials. This will increase the utilisation of abundant Nigerian raw materials, reduce the importation of wheat flour and hence, improve the economy of the country.
\end{abstract}

Index Terms - Breakfast cereals, Acha grains, Cashew kernels, Prawns, Plant protein, Essential amino acids.

\section{INTRODUCTION}

Breakfast cereal was defined to include ready-to-eat breakfast cereal, oats/porridge and muesli [1]. They are food products made from processed grains that is often eaten as the first meal of the day [2]. Breakfast cereals, though consumed dry in the early hours of the day, serve as a good source of strength which is vital requirement for the human body. They are not usually consumed alone but supplemented with other food classes [3]. They can be categorized into traditional hot cereals that require further heating or cooking before consumption or ready to eat cereals that is customarily eaten with cream or milk [4]. Ready to eat cereals are increasingly gaining acceptance in most developing countries and gradually displacing most

Published on September 17, 2020.

N. J. T. Emelike, Rivers State University, Port Harcourt, Nigeria. (e-mail: njtemelike.nkechi@yahoo.com)

S. C. Achinewhu, Rivers State University, Port Harcourt, Nigeria.

C. O. Ebere, Rivers State University, Port Harcourt, Nigeria. traditional diets that serve as breakfast due to convenience, nutritional values and job demands [5].

Acha (Digitaria exilis) is one of the world's fastest growing grains and its highly nutritious [6] like other cereals such as wheat, rice and maize. Temple and Bassa [7] stated that Acha contains $6.9 \%$ protein, $2.10 \%$ fat, $87.48 \%$ carbohydrate, $1.02 \%$ crude fibre and $2.44 \%$ mineral salts. Anyika [8] also indicated crude protein content of 5.75, fat $3.35,1.08$ total ash, 6.83 moisture and $83.38 \%$ carbohydrate values of acha. It is highly rich in carbohydrate and protein, as well as sulphur containing essential amino acids such as methionine and cystine compare to legumes [9]-[11]. Acha can be supplemented to a protein rich foods to make an adequate diet [7] or as a complement for standard diets [12], depending on the contents of the second limiting amino acids like threonine in cereals and tryptophan in legumes [13] such as pap and bean balls, a popular Nigerian breakfast made from maize and beans.

Cashew nut (Anacardium occidentale) is a heart-like shaped fruit grown in Africa and West Indies [14]. In the last few years, the production of cashew nuts in Nigeria has increased from 30,000 tons in 1990 to 176,000 tons in 2000 [15]. About $60 \%$ of cashew kernels are consumed in form of snacks while $40 \%$ are used in the manufacture of confectioneries [16]. Cashew kernel is a rich source of fat $46 \%$ and carbohydrates $25 \%$, protein within a range of 20.5$21.0 \%$, crude fibre $1.2-1.5 \%$ and a good source of calcium, phosphorus and iron [17], [18]. Brufau et al. [19] also stated that the edible part of the nut contains $47.8 \mathrm{~g}$ crude fat, $29.9 \mathrm{~g}$ carbohydrate, $16.8 \mathrm{~g}$ protein and $574 \mathrm{kcal}$ energy per $100 \mathrm{~g}$ intake.

Prawn is a popular food material for consumers because of its delicacy and rich nutrient density. Prawns are relatively inexpensive excellent source of animal protein and several vitamins and minerals. They have become the major source of animal protein to the low income earners due to their low price and availability [20], predominantly in developing countries where animal protein is pricey and beyond the reach of the underprivileged [21]. In addition to its supply of quality proteins and vitamins (A, C and D), they are good source of dietary minerals such as calcium, phosphorus, iron, magnesium among others, which are beneficial for human maintenance [22]. Minerals are essential chemical elements which are involved in the building of human body and are necessary for appropriate functioning of the immune system [23].

Most cereals are limited in some essential amino acids like threonine and tryptophan, though rich in lysine but cannot effectively provide nutrients required by the body especially during the early hours of the day when the supply 
of nutrients from the previous day is exhausted [24]. However, blends and consumption of proteins from plant sources and cereals in food product development is required [25], [26], since combination of legumes and grains provide high quality cheaper protein that contains all essential amino acids in proper proportion, because their amino acids complement each other [27]. Cereals can also be supplemented with most cheap and abundant oily seeds, nuts and animal products such as prawn to improve the nutritional value of the resulting cereal blends compared to the individual components alone [28]. Hence, this study aimed to formulate breakfast cereals from the blends of acha, wheat, cashew kernel flours and prawn powder and to evaluate the nutritional, functional and organoleptic properties of the resultant blends.

\section{MATERIALS AND METHOD}

\section{A. Materials}

Acha (Digitaria exilis) grains were purchased from Jalingo, Taraba State, cashew (Anacardium occidentale) nuts were purchased from $9^{\text {th }}$ mile market, Enugu State while prawns, wheat flour, sugar and sunflower cooking oil were purchased from Shoprite Supermarket, Port Harcourt, Rivers State. All these materials were transferred to the Laboratory of Food Science and Technology Department, Rivers State University, Port Harcourt, Nigeria for processing and analysis. All chemicals used for this study were obtained from the same Department and of analytical grade.

\section{B. Sample Preparation}

Acha grains and cashew nuts were properly cleaned and sorted to remove dirt and other extraneous matter, the prawns were selected to ensure they are free from diet and small stones while wheat was properly sieved before they were used for further processing.

\section{Processing of Acha Grains and Cashew Nuts into Flour and Prawns into Powder}

Acha grains and cashew nuts were processed into fours using the method described by Ibrahim [29] and Emelike et al. [30], respectively. Prawns were processed into powder by removing their head after sorting out of unwanted ones. The main body of the prawns were grounded into powdery form using Kenwood kitchen blender (model A907D, U.K) and they were sieved using $0.4 \mathrm{~mm}$ particle size sieve and packaged in air tight container for further usage.

\section{Preparation of the Breakfast Cereals}

Breakfast cereals were prepared using the method of Usman [5] with some modifications. Composite flour was formulated from varying quantities of acha/wheat and constant quantities of cashew kernel/prawn at the ratios of 70:0:20:10, 60:10:20:10, 50:20:20:10, 40:30:20:10, 30:40:20:10, 20:50:20:10, 10:60:20:10, 0:70:20:10 (acha/wheat/cashew kernel/prawn) and labeled A-H samples, respectively as presented in Table 1. Sugar, vegetable oil and water were appropriately mixed together with the individual samples at constant quantities of $5 \mathrm{~g}$, $10 \mathrm{ml}$ and $100 \mathrm{ml}$, consecutively and baked in an oven at $150^{\circ} \mathrm{C}$ for $40 \mathrm{~min}$. The samples were cooled at room temperature and adequately packaged until required for further analysis.

TABLE 1: FORMULATION FOR BREAKFAST CEREALS FROM THE FLOURS OF ACHA, WHEAT, CASHEW KERNELS AND PRAWN POWDER

\begin{tabular}{|c|c|c|c|c|c|c|c|c|}
\hline \multirow[b]{2}{*}{ Ingredients } & \multicolumn{8}{|c|}{ Samples } \\
\hline & $\mathrm{A}$ & B & $\mathrm{C}$ & $\mathrm{D}$ & $E$ & $\mathrm{~F}$ & $G$ & $\mathrm{H}$ \\
\hline $\mathrm{AF}(\mathrm{g})$ & 70 & 60 & 50 & 40 & 30 & 20 & 10 & 0 \\
\hline WF (g) & 0 & 10 & 20 & 30 & 40 & 50 & 60 & 70 \\
\hline $\mathrm{CF}(\mathrm{g})$ & 20 & 20 & 20 & 20 & 20 & 20 & 20 & 20 \\
\hline PP (g) & 10 & 10 & 10 & 10 & 10 & 10 & 10 & 10 \\
\hline Sugar (g) & 5 & 5 & 5 & 5 & 5 & 5 & 5 & 5 \\
\hline Oil (ml) & 10 & 10 & 10 & 10 & 10 & 10 & 10 & 10 \\
\hline Water (ml) & 100 & 100 & 100 & 100 & 100 & 100 & 100 & 100 \\
\hline
\end{tabular}

Key: AF: Acha Flour, WF: Wheat Flour, CF: Cashew Flour, PP: Prawn Powder.

\section{E. Analysis of the Produced Breakfast Cereal Blends}

\section{a) Proximate evaluation}

The cereal breakfast blends were evaluated of moisture, crude fat, crude protein, total ash and crude fibre using the approved standard of AOAC [31] method while carbohydrate was determined the Clegg Anthrone method as described by Osborne and Voogt [32].

\section{b) Functional evaluation}

Bulk density, water absorption, oil absorption and gelation capacities of the breakfast cereal blend samples were determined using the method described by Onwuka [33].

\section{c) Sensory evaluation}

The eight formulated samples of the cereal blends were served to 20 panelists consisting of students and staff of the Department of Food Science and Technology, Rivers State University, Port Harcourt at about 9:30am using a 9-point hedonic scale ranging from 1-9 which represented dislike extremely and like extremely, respectively. The samples were served with warm water and milk for the final preparation of the breakfast cereals. The panelists were instructed to assess the product for taste, aroma, appearance, mouth feel, crispness and overall acceptability. Portable drinking water and disposable cups were provided for the panelists for raising of their mouths in between the assessment of each sample to prevent the transfer of sensory parameters from one sample to another [34].

\section{F. Statistical Analysis}

All data obtained were subjected to a one-way Analysis of Variance (ANOVA) using Statistical Package for Social Science (SPSS), version 20.1, year 2011. Least Significant Differences (LSD) test was used to separate the means where significant difference existed at $5 \%$ levels of probability. 
Results were expressed as mean values and standard deviation of triplicate determinations.

\section{RESUlts AND DiscUSSION}

\section{A. Proximate Compositions of the Breakfast Cereal Blends}

The proximate composition of the blends formulated from acha, wheat, cashew kernel and prawn revealed that there was a significant difference $(p<0.05)$ in the moisture content of some samples while there was not in some others with the range of $3.94-9.45 \%$ for samples $\mathrm{H}$ as the highest and $\mathrm{B}$ the lowest as presented in Table 2. It was observed that the increasing substitution level of acha flour caused a decreased in the moisture content of the blends. Generally, the samples had low moisture content which implied that they could have an extended shelf life in their raw form. It has been stated that moisture content of a food affects its stability and overall quality [35].

The ash content of the blends ranged from 2.09-2.98\% with no significant difference $(\mathrm{p}<0.05)$ among all the samples. Ash content of the breakfast cereals decreased with increased in acha flour substitution. Ash content is the residue remaining after destroying combustible organic matter. The value of the ash obtained is comparable to the value of $1.98 \%$ to $2.40 \%$ reported by Usman et al. [36] for breakfast cereals formulated from local rice, soya beans and defatted coconut flours. The ash content gives an overall estimate of the total mineral elements present in the food.

Values for crude fat ranged from $8.30-15.20 \%$ (E and B samples, respectively) with significant difference $(\mathrm{p}<0.05)$ among all the samples excluding $\mathrm{G}$ and $\mathrm{H}$ samples. Dietary fat that provides essential fatty acids has been shown to enhance the taste and acceptability of food products, slows gastric emptying and intestinal motility. Thus, prolonging satiety and facilitating the absorption of water soluble vitamins [37].

There was no significant difference $(p<0.05)$ in the protein content of samples B, C, E and F while samples D, G and H had significantly highest values of $14.64,14.35$ and $14.65 \%$, respectively. The protein content of the blends was higher than that of pap known as ogi in Yoruba and akamu in Igbo tribes, a popular Nigerian breakfast cereal which has been reported to contain $10.92 \%$ protein [35]. This implies that the formulated breakfast cereals in this study will serve as a good source of protein. Hence, consuming it will enable the body to derive good amount of protein which will enhance day-to-day activities of the body system than the popular known ogi. This could however help in preventing proteincarbohydrate malnutrition which is wide spread in Africa.

Fibre content ranged from $1.28-1.60 \%$ for samples $G$ and $\mathrm{H}$ with significantly lowest and highest values, respectively. Fibre is important for the removal of waste products from the body thereby preventing constipation, colon cancer, heart failure and many other health disorders. Consumption of plant fibre has been shown to reduce cholesterol level, risk of coronary heart diseases and insulin sensitivity [35]. The fibre content of the breakfast cereals was lower as compared to that formulated from blends of local rice, soybeans and defatted coconut flour with values of $2.11-3.30 \%$ [36]. This could be attributed to the natural fibre contents of the food materials used in the blends.

TABle 2: Proximate COMPOSITIONS OF THE BREAKFAST CEREAL BlendS

\begin{tabular}{|c|c|c|c|c|c|c|}
\hline Sample & Moisture (\%) & Ash (\%) & Fat $(\%)$ & Protein $(\%)$ & Fibre $(\%)$ & Carbohydrate $(\%)$ \\
\hline $\mathrm{A}$ & $6.93 \pm 0.05^{\mathrm{b}}$ & $2.09 \pm 0.10^{\mathrm{ab}}$ & $12.99 \pm 0.01^{\mathrm{c}}$ & $9.17 \pm 0.00^{\mathrm{d}}$ & $1.35 \pm 0.02^{\mathrm{bc}}$ & $67.48 \pm 0.15^{\mathrm{c}}$ \\
\hline B & $3.94 \pm 0.25^{\mathrm{d}}$ & $2.14 \pm 0.24^{\mathrm{ab}}$ & $15.20 \pm 0.00^{\mathrm{a}}$ & $13.06 \pm 0.00^{\mathrm{bc}}$ & $1.42 \pm 0.01^{\mathrm{b}}$ & $64.25 \pm 0.02^{\mathrm{d}}$ \\
\hline $\mathrm{C}$ & $7.49 \pm 0.47^{b}$ & $2.54 \pm 0.95^{\mathrm{a}}$ & $14.35 \pm 0.05^{\mathrm{b}}$ & $13.06 \pm 0.00^{\mathrm{bc}}$ & $1.32 \pm 0.00^{c}$ & $61.25 \pm 0.43^{\mathrm{e}}$ \\
\hline $\mathrm{D}$ & $4.19 \pm 0.10^{\mathrm{d}}$ & $2.39 \pm 0.30^{\mathrm{a}}$ & $10.80 \pm 0.10^{\mathrm{d}}$ & $14.64 \pm 0.22^{\mathrm{a}}$ & $1.33 \pm 0.01^{\mathrm{c}}$ & $76.66 \pm 0.28^{\mathrm{a}}$ \\
\hline $\mathrm{E}$ & $4.91 \pm 0.02^{\mathrm{cd}}$ & $2.13 \pm 0.05^{\mathrm{ab}}$ & $8.30 \pm 0.00^{\mathrm{f}}$ & $13.30 \pm 0.22^{\mathrm{b}}$ & $1.42 \pm 0.00^{\mathrm{b}}$ & $69.95 \pm 0.15^{\mathrm{b}}$ \\
\hline $\mathrm{F}$ & $5.21 \pm 0.07^{\mathrm{c}}$ & $2.22 \pm 0.13^{\mathrm{a}}$ & $12.41 \pm 0.01^{\mathrm{c}}$ & $13.46 \pm 0.35^{\mathrm{b}}$ & $1.55 \pm 0.05^{\mathrm{a}}$ & $65.17 \pm 0.60^{\mathrm{d}}$ \\
\hline G & $5.11 \pm 0.07^{\mathrm{c}}$ & $2.33 \pm 0.05^{\mathrm{a}}$ & $9.40 \pm 0.00^{\mathrm{e}}$ & $14.35 \pm 0.00^{\mathrm{a}}$ & $1.28 \pm 0.03^{\mathrm{c}}$ & $67.54 \pm 0.16^{\mathrm{c}}$ \\
\hline $\mathrm{H}$ & $9.46 \pm 0.08^{\mathrm{a}}$ & $2.98 \pm 0.00^{\mathrm{a}}$ & $9.36 \pm 0.04^{\mathrm{e}}$ & $14.65 \pm 0.00^{\mathrm{a}}$ & $1.60 \pm 0.00^{\mathrm{a}}$ & $60.97 \pm 0.11^{\mathrm{e}}$ \\
\hline LSD & 0.70 & 1.22 & 0.15 & 0.47 & 0.07 & 1.04 \\
\hline
\end{tabular}

Values with the same superscript letter within the column are not statistically different $(\mathrm{p}<0.05)$.

Key: A = Acha/Wheat/Cashew kernel/Prawn (70:0:20:10), B = (60:10:20:10), C = (50:20:20:10), D = (40:30:20:10), E = (30:40:20:10), F = (20:50:20:10), $\mathrm{G}=(10: 60: 20: 10), \mathrm{H}=(0: 70: 20: 10)$.

\section{B. Functional Properties of the Breakfast Cereal Blends}

Bulk density of the breakfast cereals ranged from 0.49$0.55 \mathrm{~g} / \mathrm{g}$ for $\mathrm{C}$ and $\mathrm{H}$ samples, respectively with no significant different $(\mathrm{p}<0.05)$ in all the formulations as shown in Table 3. Bulk density gives an indication of the volume of packaging materials required, transportation of food products and it decreases porosity of materials due to surface properties [38]. High bulk density is a good physical attribute when determining the mixing quality of a particulate matter [39]. Bulk density is a reflection of the load the flour samples can carry if allowed to rest directly on one another. Higher bulk density is desirable for greater ease of dispensability of flours. In contract, however, low bulk density would be an advantage in the formulation of complementary food. The low bulk density values recorded in this study could therefore be advantageous in the preparation of weaning food formulas.

The result showed that the breakfast cereal samples had significantly $(\mathrm{p}<0.05)$ high water absorption capacity (WAC) except samples $\mathrm{F}$ and $\mathrm{G}$. There was a decrease in the WAC from $2.20-1.74 \mathrm{~g} / \mathrm{ml}$ for samples $\mathrm{A}$ and $\mathrm{G}$ as the substitution level of Acha flour decreased. A sudden increase was observed at $70 \%$ substitution level of wheat flour maintaining no significant different with the sample substituted with $70 \%$ level of acha flour. This observation could be due to the water binding, properties of acha and wheat protein. Water absorption capacity is important in bulking and consistency of product as well as in baking applications [40]. 
The oil absorption capacity (OAC) of the breakfast cereals ranged from 0.18-1.09 $\mathrm{g} / \mathrm{ml}$. Samples A, B, E and $\mathrm{H}$ were not significantly $(p<0.05)$ different from each other, as well as samples $\mathrm{C}$ and $\mathrm{D}$ while significant variation existed between $\mathrm{F}$ and $\mathrm{G}$ samples. The relativity high oil absorption capacity of the breakfast cereals suggest that it will be useful in food formulation were oil holding capacity is required such as in bakery products.

The least gelation capacity of the formulated breakfast cereals was $2 \%$ in all samples. The result of this study suggests that Acha, wheat and cashew kernel flours would be useful in food formulations such as bakery products which require hydration to improve handling features.

TABLE 3: FunCtional Properties OF The BREAKFAST CEREAL BlendS

\begin{tabular}{ccccc}
\hline Samples & Bulk Density $(\mathrm{g} / \mathrm{g})$ & Water Absorption $(\mathrm{g} / \mathrm{ml})$ & Oil Absorption $(\mathrm{g} / \mathrm{ml})$ & Least Gelation $(\%)$ \\
\hline A & $0.51 \pm 0.01^{\mathrm{a}}$ & $2.20 \pm 0.01^{\mathrm{a}}$ & $0.20 \pm 0.00^{\mathrm{d}}$ & 2 \\
B & $0.54 \pm 0.01^{\mathrm{a}}$ & $2.04 \pm 0.05^{\mathrm{a}}$ & $0.19 \pm 0.02^{\mathrm{d}}$ & 2 \\
C & $0.49 \pm 0.04^{\mathrm{a}}$ & $2.07 \pm 0.09^{\mathrm{a}}$ & $1.09 \pm 0.01^{\mathrm{a}}$ & 2 \\
D & $0.52 \pm 0.01^{\mathrm{a}}$ & $2.05 \pm 0.00^{\mathrm{a}}$ & $1.02 \pm 0.01^{\mathrm{a}}$ & 2 \\
E & $0.52 \pm 0.04^{\mathrm{a}}$ & $2.07 \pm 0.12^{\mathrm{a}}$ & $0.18 \pm 0.03^{\mathrm{d}}$ & 2 \\
F & $0.51 \pm 0.02^{\mathrm{a}}$ & $1.76 \pm 0.03^{\mathrm{b}}$ & $0.80 \pm 0.00^{\mathrm{b}}$ & 2 \\
G & $0.50 \pm 0.00^{\mathrm{a}}$ & $1.74 \pm 0.01^{\mathrm{b}}$ & $0.34 \pm 0.05^{\mathrm{c}}$ & 2 \\
H & $0.55 \pm 0.03^{\mathrm{a}}$ & $2.19 \pm 0.00^{\mathrm{a}}$ & $0.20 \pm 0.00^{\mathrm{d}}$ & \\
\hline LSD & 0.20 & 0.07 & 0.03 &
\end{tabular}

Values with the same superscript letter within the column are not statistically different $(\mathrm{p}<0.05)$.

Key: $\mathrm{A}=$ Acha/Wheat/Cashew kernel/Prawn (70:0:20:10), $\mathrm{B}=(60: 10: 20: 10), \mathrm{C}=(50: 20: 20: 10), \mathrm{D}=(40: 30: 20: 10), \mathrm{E}=(30: 40: 20: 10), \mathrm{F}=$ (20:50:20:10), $\mathrm{G}=(10: 60: 20: 10), \mathrm{H}=(0: 70: 20: 10)$.

\section{Organoleptic Properties of the Breakfast Cereals}

The result showed that the score for taste of the breakfast cereals ranged from $4.40-7.10$ with sample $\mathrm{A}$ as the least preferred and sample $\mathrm{G}$ as the most preferred as presented in Table 4. There was no significant different $(p<0.05)$ between C, D, E, F, G and H samples while samples A and B had significantly low sensory scores. This implies that the taste of the breakfast cereals was acceptable up to 50:20 of acha/wheat flours but the most acceptable taste was the formulation of up to $40 \%$ level of acha. Chukwu and AbdulKadir [41] reported that acha contributed to the good taste of breakfast cereals. Scores for aroma and appearance ranged from $5.30-6.45$ and 5.45-7.10 with samples $\mathrm{F}$ and $\mathrm{H}$ as least and most preferred and same as B and C samples, respectively. Mouth-feel ranged from 5.65-6.70 with sample $\mathrm{F}$ as least preferred and $\mathrm{H}$ the most preferred. There was no significant different between samples $C, D, E, G$ and $H$ with the highest scores for mouth-feel while others had low sensory scores. Crispness ranged from 5.75-6.90 with samples A and B as least preferred in both cases and sample $\mathrm{G}$ as the most preferred. Overall acceptability of the breakfast cereals ranged from 5.25-6.95 with sample $G$ as the most preferred and sample $\mathrm{A}$ as least preferred. The overall acceptability of the breakfast cereals produced with $40 \%$ acha substitution level to wheat compared favourably with those produced with $0 \%$ acha level. This is in agreement with the report of Mbaeyi-Nwaoha and Uchendu [42] who started that the sensory qualities of breakfast cereals produced from the blends of acha and fermented soybean paste were acceptable by the panelists. This signifies that breakfast cereals can be formulated from the blends of acha/wheat/cashew kernel/prawn at the ratios of 40:30:20:10, respectively without altering the sensory characteristics of the product.

\begin{tabular}{|c|c|c|c|c|c|c|}
\hline B & $4.75^{\mathrm{c}}$ & $5.80^{\mathrm{b}}$ & $5.45^{\mathrm{c}}$ & $6.00^{\mathrm{b}}$ & $5.75^{\mathrm{b}}$ & $5.50^{\mathrm{b}}$ \\
\hline D & $6.80^{\mathrm{a}}$ & $6.35^{\mathrm{a}}$ & $6.60^{\mathrm{a}}$ & $6.55^{\mathrm{a}}$ & $6.40^{\mathrm{ab}}$ & $6.20^{\mathrm{ab}}$ \\
\hline $\mathrm{E}$ & $6.25^{\mathrm{ab}}$ & $6.00^{\mathrm{ab}}$ & $6.30^{\mathrm{ab}}$ & $6.20^{\mathrm{ab}}$ & $6.80^{\mathrm{a}}$ & $6.35^{\mathrm{ab}}$ \\
\hline $\mathrm{F}$ & $6.20^{\mathrm{ab}}$ & $5.30^{\mathrm{bc}}$ & $6.45^{\mathrm{a}}$ & $5.65^{\mathrm{b}}$ & $6.20^{\mathrm{ab}}$ & $6.70^{\mathrm{a}}$ \\
\hline LSD & 0.96 & 1.01 & 0.80 & 0.98 & 0.90 & 1.00 \\
\hline
\end{tabular}

Values with the same superscript letter within the column are not statistically different $(\mathrm{p}<0.05)$.

Key: $\mathrm{A}=$ Acha/Wheat/Cashew kernel/Prawn $(70: 0: 20: 10), \mathrm{B}=(60: 10: 20: 10), \mathrm{C}=(50: 20: 20: 10), \mathrm{D}=(40: 30: 20: 10), \mathrm{E}=(30: 40: 20: 10), \mathrm{F}=$ (20:50:20:10), $\mathrm{G}=(10: 60: 20: 10), \mathrm{H}=(0: 70: 20: 10)$.

\section{CONCLUSION}

The produced breakfast cereals were rich in protein, fat, carbohydrates and ash contents. Hence, this product can solve the problems of protein energy malnutrition in developing counties and the flour blends can serve as functional ingredient in food formulations. Substitution of acha flour up to $40 \%$ compared favorably with the highest level of wheat substitution which is $70 \%$ in all the organoleptic properties measured. This signifies that acceptable breakfast cereals formulated from acha, wheat, cashew kernel and prawn flours were produced. This study has provided another means for the utilisation of acha cereal grains, cashew kernel and prawns. The observed decrease in moisture content at increasing substitution levels of acha flour proves that the product will have an extended shelf life when passably packaged. 


\section{REFERENCES}

[1] Williams PG (2014). The Benefits of Breakfast Cereal Consumption: A Systematic Review of the Evidence Base 1-4. Advances in Nutrition 5, 636S-673S. doi:10.3945/an.114.006247. Downloaded from advances.nutrition.org at Nigeria: American Society for Nutrition (ASNA) Sponsored on July 3, 2015.

[2] Lawrence F (2006). "How constipation cure became huge business". The Guardian. London. Retrieved 2008-04-20.

[3] Enwere NJ (1998). Foods of Plant Origin. Afro-Orbis Publications Ltd. Pp. 194-199.

[4] Encyclopaedia Britannica (2018). Breakfast Cereal. Encyclopaedia Britannica, Inc. Published August 10, 2018. https://www.britannica.com/topic/breakfast-cereal.

[5] Usman O.G (2013). Production and evaluation of breakfast cereal from blends of Africa yam bean (Sphenostylisstenocarpa), maize (zea may) and defatted coconut (Cocosnuccifera). An M.Sc Dissertation, Department of Food Science and Technology, University of Nigeria, Nsukka.

[6] Wagner J (2007). Exports and productivity: A survey of the evidence from firm-level data. The World Economy, 30(1), 60-82. Doi.org/10.1111/j.1467-9701.2007.00872.x.

[7] Temple V.J and Bassa J.D (1991). Proximate chemical composition of Acha (Digitaria exilis) grain. J. Sci. Food Agric., 56: 561-563.

[8] Anyika J.U (2003). Iron and phosphorus utilization in rats fed soaked and dehulled bambara groundnut supplemented with sorghum or crayfish. Plant Foods for Human Nutrition, 58(1), 53-61.

[9] Jideani A.I.O and Akingbala J.O (1993). Some physical properties of acha (Digitaria exilis) and Iburu (Digitaria iburua) Grains. Journal of the Science of Food and Agriculture, 63(3), 369-374. Doi: $10.1002 /$ jsfa. 2740630317.

[10] Belton PS, Nuttall JR (2002). Pseudocereals and Less Common Cereals: Grains Properties and Utilisation Potential. Springer, Berlin Heidelberg.

[11] Vodouhè SR, Achigan DE, Dansi A and Adoukonou SH (2012). Fonio: A Treasure for West Africa Briefing by the International Plant Genetic Resources Institute (West and Central Africa Sub-Office) and Crop, Aromatic and Medicinal Plant Biodiversity Research and Development Institute (IRDCAM). Retrieved from www.underutilizedspecies.org/documents/publications/rv.

[12] NAS (1996). National Academy of Sciences. Lost Crops of Africa: Vol. 1: Grains. Washington D.C. National Academy Press.

[13] Duranti M (2006). Grain legume proteins and nutraceutical properties. Fitoterapia, 77(2), 67-82. Doi:10.1016/j.fitote.2005.11.008.

[14] Aremu M.O, Olonisakin A, Bako D.A and Madu P.C (2006). Compositional studies and physicochemical characteristics of cashew nut (Anacardium occidentale) flour. Pakistan Journal of Nutrition, 5(4), 328-333.

[15] FAO (2000). Cashew production in Africa, 1961-2000. Food and Agriculture Organization of the United Nations. Production Database, http://apps.fao.org/.

[16] UNIDO (2011). Tanzania Cashew Value Chain: Diagnosite. United Nations Industrial Development Organization (UNIDO) Vienna, Austria P.66.

[17] Fetuga B, Batunde G and Oyenuga V (1974). Composition and nutritive value of cashew nut to the rat. Journal of Agriculture and Food Chemistry 572: 672,678.

[18] Emelike N.J.T and Ebere C.O (2015). Influence of processing methods on the tannin content and quality characteristics of cashew byproducts. Agriculture and Food Sciences Research, 2(2), 56-61.

[19] Brufau G, Boatella J and Rafecas M (2006). Nuts: source of energy and macronutrients. British Journal of Nutrition, 96(2), S24-S28. Doi: 10.1017/BJN20061860.

[20] Adeyeye E.I (1996). Waste yield, proximate and mineral composition of three different types of land snails found in Nigeria. International Journal of Food Sciences and Nutrition, 47(2), 111-116.

[21] Bello-Olusoji AO, Oke A (2005). Chemical index and organoleptic assessment of freshness of frozen and oven dried African river prawn. M. vollenhovenii during storage. Journal of Tropical Biosciences, 5(1), 154-157.

[22] Abulude FO, Lawal LO, Ehikhamen G, Adesanya WO, Ashafa SL (2006). Chemical composition and functional properties of some prawns from the coastal area of Ondo state, Nigeria. Electron. Journal of Environmental, Agricultural and Food Chemistry, 5(1), 1235-1240.

[23] Steffens W (1989). Principles of Nutrition. Ellis Harwood Limited, UK.

[24] Onweluzo J.C and Nnamuchi O.M (2009). Production and evaluation of porridge-type breakfast product from Treculia Africana and Sorghum bicolor flours. Pakistan Journal of Nutrition, 8(6), 731-736. Doi: 10.3923/pjn.2009.731.736.
[25] Ofuya ZM and Akhidue V (2005). The role of pulses in human nutrition: a review. Journal of Applied Sciences and Environmental Management, 9(3), 99-104. Doi.org/10.4314/jasem.v9i3.17361.

[26] Okafor G.I and Usman G (2015). Physical and functional properties of breakfast cereals from blends of maize, African yam bean, defatted coconut cake and sorghum extract. Food Science and Quality Management, 40, 25-34.

[27] Okaka J.C (2005). Basic Processing of Grain Cereals and Legumes in Handling, Storage and Processing of Plant Foods. OCJ Academic Publishers, Enugu, Nigerian, pp. 30-60.

[28] Kanu P.J, Sandy E.H, Kandeh B.A, Behsoon J.Z and Huiming Z (2009). Production and evaluation of breakfast cereal-based porridge mixed with sesame and pigeon peas for adults. Journal of Nutrition, 8(9), 1335-1343. Doi: 10.3923/pjn.2009.1335.1343.

[29] Ibrahim A (2001). Hungry Rice (Acha): a neglected cereal crop. NAQAS Newsletter, 1(4), 4-5.

[30] Emelike N.J.T, Barber L.I and Ebere C.O (2015). Proximate, mineral and functional properties of defatted and undefatted cashew (Anacardium occidentale linn.) kernel flour. European Journal of Food Science and Technology, 3(4), 11-19.

[31] AOAC (2012). Association of Official Analytical Chemist. Association of Analytical Chemist. 15th Edition. Washington D.C.

[32] Osborne D.R and Voogt P (1978). The Analysis of Nutrition in Foods. London Academic Press, 130-134.

[33] Onwuka G.I (2005). Food Analysis and Instrumentation: Theory and Practice. Naphthali Prints, Lagos, Nigeria.

[34] Iwe MO (2010). Handbook of Sensory Methods and Analysis, 75-78. Enugu Nigeria Rejoint Communication Science Ltd.

[35] Folake O.S and Bolanle O.O (2006). Chemical analysis and sensory evaluation of ogi enriched with soybeans and crayfish. Nutrition and Home Science, 36(4), 214-217. Doi:10.1108/00346650610676785

[36] Usman GO, Ameh UE, Alifa ON, Babatunde RM (2015). Proximate composition and anti-nutrient properties of breakfast cereal made from blends of local rice, soybeans and defatted coconut flours. Journal of Nutrition and Food Sciences, 11(6), 1-3. Doi: 10.4172/21559600.1000S11-006

[37] Ebuchi OAT and Oyewole AC (2008). Effect of cooking and soaking on physical characteristics, nutrient composition and sensory evaluation of indigenous and foreign rice varieties in Nigeria. Nutrition and Food Science, 38(1), 15-21. Doi: 10.1108/00346650810847972.

[38] Milson T.S and Kirk P.C (1980). Legumes in human nutrition. Food and Agriculture Organisation of Nutrition Series, 19, 223-235.

[39] Lewis M.J (1990). Physical Properties of Food and Food Processing Systems. 2nd Edn., Hartnolls Limited, Bodman Cornwall, Great Britain.

[40] Niba L.L, Bokanga M.M., Jackson F.L., Schimme D.S. and Li B.W. (2002). Physicochemical properties and starch granular characteristics of flour from various Manihot esculenta (Cassava) genotypes. Journal of Food Science, 67(5), 1701-1705. Doi: 10.1111/j.13652621.2002.tb08709.x

[41] Chukwu O and Abdul-Kadir JA (2008). Proximate chemical composition of acha (Digitaria exilis and Digitaria iburua) grains. Journal of Food Technology, 6(5), 214-216.

[42] Mbaeyi-Nwaoha I.E and Uchendu N.O (2016). Production and evaluation of breakfast cereals from blends of acha and fermented soybean paste (okara). Journal of Food Science and Technology, 53(1), 50-70.

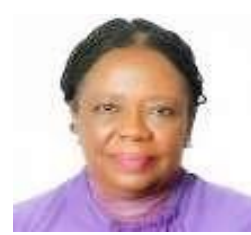

Emelike, Nkechi Juliet Tamuno was born in Bonny Town, Rivers State, Nigeria on the 27th day of March, 1955. She obtained her B.Sc Degree in Home Science from Punjab University, Chandigarh, India in 1982. She graduated with M.Phil and Ph.D in Food Science \& Technology from Rivers State University, Nigeria in 1989 and 2014, respectively.

Her major field of study is in Food Analysis and New Food Product Development. She worn several award for workshops and training of Local Food Processors and handler such as "Bread Producers Association of D/Line, Port Harcourt", "Pillar of Association Group of Port Harcourt" "Kuruama Fish Dryers Association of Kala- Iwoma". She is currently a Reader in Rivers State University, Port Harcourt and has published numerous articles on Cashew Kernel utilization of which few are:

[1] Effect of packaging materials, storage time and temperature on the colour and sensory characteristics of cashew (Anacardium occidentale L.) Apple Juice. Journal of Food Science and Nutrition Research, 3(7): 410-414.

[2] Physico-chemical and sensory properties of cookies from wheat flour 
and cashew-apple residue as a source of fiber. Asian Journal of Agriculture and Food Science, 3(2): 213-218.

[3] Effect of treatments on the tannin content and quality assessment of cashew apple juice and the kernel. European Journal of Food Science and Technology, 5(4): 47-53.

She has been lecturing at the Food Science and Technology Department of the Rivers State University, Port Harcourt, Nigeria, rising through the ranks of Graduate Assistant in 1983 to a Reader. She has over forty published articles in both international and local journals. She has been an active member of American Institute of Food Science and Technology (IFT), Nigerian Institute of Food Science and Technology (NIFST), Mycological Association of Nigeria (Mycosan), Home Economic Research Association of Nigeria (Heran) among others.

She has worn awards and has been recognized by Trade groups as well as small scale industrialist such as "Bread Producers of D/Line, Port Harcourt" "Plantain Roasters Association of Borokiri" "Kuruama Fishers' for successful food processing and preservation workshop. 